\title{
ALL MALE NILE TILAPIA OREOCHROMIS NILOTICUS FRY NURSING IN NET CAGES AT HAOR OF SUNAMGANJ, BANGLADESH
}

\author{
M.S. Islam* and N. Begum \\ Department of Coastal and Marine Fisheries \\ Sylhet Agricultural University, Sylhet-3100, Bangladesh
}

\begin{abstract}
Nile tilapia (Oreochromis niloticus) of average $2.08 \pm 0.06$ to $2.14 \pm 0.19$ $\mathrm{g}$ fry nursed in nine-floating net-cages of $3 \times 3 \times 1.5 \mathrm{~m}$ in high stocking densities of 600,800 and 1000 fry $\mathrm{m}^{-3}$ densities in triplicate. The fish were hand-fed a commercial tilapia floating feed at a rate of 5 to $30 \%$ of their body weight thrice daily. The final mean weight of tilapia ranged $15.13 \pm 0.28$ to $24.10 \pm 0.35 \mathrm{~g}$ with the mean daily weight gain of $0.21 \pm 0.11$ to $0.38 \pm 0.05 \mathrm{~g} /$ day. The low stocking density of 600 fry $\mathrm{m}^{-3}$ had significant higher mean weight, daily growth rate and specific growth rate than did the higher density treatment of 1000 fry $\mathrm{m}^{-3}$. The food conversion ratio were (1.46 to 2.30 ) significantly affected by stocking density $(\mathrm{p}<0.05)$. Moreover, the net profit (BDT $1262 \pm 85-2152 \pm 55$ ) showed a significant difference with increasing stocking density $(\mathrm{p}<0.05)$. The growth of nursing fry was found to be density dependent. However, survival rates were found high in all treatments and were not affected by density. But, higher gross yield was observed at the highest density. The results of this study has clearly demonstrated that the higher density ( 800 and 1000 fry $\mathrm{m}^{-3}$ ) could be more profitable for tilapia cages than the lower density (600 fry $\mathrm{m}^{-3}$ ) in terms of cost effectiveness and to meet the demand for large scale fish production.
\end{abstract}

Key words: Nile tilapia, net cages, haor ecosystem, stocking densities, growth performance, gross yield, profitability, Sunamgonj, Bangladesh

\section{INTRODUCTION}

Cage aquaculture is playing an increasingly important role in the world for food fish supply of high market value fish species but also for the most common fishes like tilapias and carps. Cage culture can provide low-cost alternative to conventional land-based nurseries and may be employed in culturing fastswimming pelagic species (Beveridge 1996). Cage farming is a popular practice in Bangladesh and fingerlings production in cages is a new practices. It has certain advantages over other aquaculture systems. The success of the cage technologies particularly fingerling production in open waterbody is a useful opportunity to get access for setting cages by the non-owners of waterbodies. Getting access to waterbodies with minimum investment, the landless households can produce fingerling in cages and get income earning (Naser and Barman 2009). The most appropriate species of for cage culture is Nile tilapia.

*Author for correspondence: <islamms2011@yahoo.com>

(c) 2018 Zoological Society of Bangladesh DOI: https://doi.org/10.3329/bjz.v47i1.42053 
The choice of a species for culture depends mainly on availability, growth performance and survival of a fish (McGinty and Rakocy 2006). Tilapia is regarded as the second most cultured species globally because of its easy adaptation to tropical and sub-tropical waters (Shelton 2002). In Bangladesh the GIFT strains of sex-reversed male tilapia are most popular culture species owing to favorable for any kind of waterbody.

Bangladesh has huge volume of seasonal waterbodies such as haors (naturally depressed seasonal-perennial open waterbody), floodplains, rivers, baors (ox-bow lakes), reservoirs, irrigation canals and estuaries. Haor region is naturally enriched with various resources. People of haor region typically capture fish from the haor not culture. Due to decreasing trend of fish in the haor, they are now getting interest to culture fish in cage in open water. One of the major constraints of fish culture in haor is non-availability of quality fish fry/fingerlings. Fish culture by using fingerlings is more cost effective and profitable than fish fry. Fingerlings may be transported from a long distance with high price to haor area usually incur high fingerlings mortality. Fingerling production in cages in the reservoir reduces transport costs and minimizes fingerlings mortality, and more cost effective than using either pens or nurseries (Das et al. 2009). To meet the growing demand of quality fingerlings, rearing fry incage would be one of the good options especially in haor.

Identification and recommendation of the ideal stocking densities for fingerling production in net cage is utmost important for the maximization of its production and profitability. However, sporadic works have been done on the performance of the improved strain of tilapia under different stocking densities in Bangladesh. The objective of this study was to evaluate the effects of stocking densities on growth performance, yield and economic profitability of all male Nile tilapia fingerling production in net-cages in haor.

\section{MATERIAL AND METHODS}

This study was conducted in the Dekar haor, one of the most important wetland of Bangladesh. The haor is situated by the side of Sylhet-Sunamganj highway and closed to Sunamganj district town and is surrounded by four Upazilas namely Dakshin Sunamganj, Sunamganj sadar, Dowarabazar and Chhatak of Sunamganj district. The study area is located in between $24.46^{\prime}$ and $24.57^{\prime}$ north latitudes and in between $91.20^{\prime}$ and $91.31^{\prime}$ east longitudes. The nursing experiment was conducted for a period of two months, June and July 2017.

Fish: All male tilapia fry were collected from a private hatchery and were transported in oxygenated polythene bags to the net cage site. Before stocking, 
fry were acclimatized to the cage water for one hour period. Initial weight and length of random fifty fish were recorded before stocking in the cages.

Experimental: Nine newly constructed floating nylon net cages $(3 \times 3 \times 1.5 \mathrm{~m})$ were set in the periphery of the haor water. Frames of cages were made by GI pipes and aluminium drums $(250 \mathrm{~L})$ were used to float the cages in water. Netcages were made of knot less polyethylene net (mesh $1.0 \mathrm{~cm}$ ) and bamboo made platform was set up over the cages and all cages were fixed with poles of the platform. Cages were installed at both sides of the platform for easy feed supply and intensive supervision. Open part of each cage was covered with another piece of nylon net (mesh 2 to $2.5 \mathrm{~cm}$ ) to avoid escaping of fish and predation by bird. All male Nile tilapia was stocked in net cages at three densities: 600, 800 and 1000 fry $\mathrm{m}^{-3}$. Each density represented as a treatment and each treatment was triplicates in number. The place selected for setting the cages was cleaned manually and limed with $\mathrm{CaO}$ at a rate of $0.025 \mathrm{~kg} \mathrm{~m}^{-2}$. After 5 days of liming, all cages were stocked with required number of fry of male tilapia. Stocked fry of tilapia were fed with commercial pellet floating feed at a decreasing rate of 30$5 \%$ of body weight thrice daily until the previous day of harvest. Feeding rates were adjusted every 10 day intervals depending on the body weight of stocked tilapia. Proximate compositions such as moisture, crude protein, crude lipid, ash, crude fiber and carbohydrate of supplemented feed were 11, 30, 7, 15, 8 and $29 \%$, respectively.

Fish Sampling and data analysis: Ten day intervals sampling was done to determine growth of tilapia and to adjust the feed rations. Growth was measured regarding weight (g) with digital balance (CAMRY digital balance Model EK 3052, Bangladesh) and length by measuring scale. Tilapias were totally harvested after 60 days of culture duration. They were caught by using hand scoop net and lifting all cages from water on the same day. After harvest, all tilapia of cages were counted and weighed individually to determine growth survival rate and yield. Specific growth rates (SGR), food conversion ratio (FCR), Survival rate (\%) were calculated following the equation as described by Pechsiri and Yakupitiyage (2005).

The yield of fish (No. of fish caught $\times$ (average final weight of fish - average initial weight fish) and Economic analyses of the different treatments was reckoned on the basis of purchasing prices of tilapia fry, feed, fertilizer, lime, transport cost and revenue from the sale of harvested tilapia. At the end of the study, all fish were sold on the spot. Tilapias were sold at a rate of BDT 3.75 to 4.00/fingerling. All items expressed in Bangladesh taka, BDT ( 1 USD $=80$ BDT). Net profit and cost-benefit ratio (BCR) indices were calculated after harvest the fishes. 
Water quality variables: Water quality variables like surface temperature, transparency, dissolved oxygen concentration (DO), $\mathrm{pH}$, total alkalinity and ammonia were monitored at 10 day intervals between 9 and 10 am at the time of fingerlings sampling. Surface water temperature was measured on the spot using a standard centigrade thermometer. Transparency was recorded using Secchi disc. Dissolved oxygen concentration was measured by using a portable DO meter (YSI 58 DO meter, HANNA, Yellow Springs, Ohio 45387 USA). pH of cage water was recorded by using a $\mathrm{pH}$ meter (HANNA, USA). Total alkalinity was measured by titrimetric method, (APHA, 2000). Nitrate-nitrogen was measured by using an ammonia test kit (Biosol, A.A. Biotech PVT LTD., Fishtech BD LTD).

All percent data were transformed into square root before statistical analysis. The mean values of experimental treatments were subjected to one-way analysis of variance (ANOVA) followed by Duncan's Multiple Range Test (DMRT) for multiple comparisons of means at 5\% level of significance using SPSS (Statistical Package for Social Science) version 20.

\section{RESULTS AND DISCUSSION}

Growth performance, growth rate and SGR: The results showed that the different growth parameters were significantly affected by stocking density (Table 1). The highest weight $(24.10 \mathrm{~g})$ of tilapia was attained at a density of 600 fry $\mathrm{m}^{-3}$ $\left(\mathrm{T}_{1}\right)$ followed by 800 fry $\mathrm{m}^{-3}\left(\mathrm{~T}_{2}\right)$ and 1000 fry $\mathrm{m}^{-3}\left(\mathrm{~T}_{3}\right)$ (Fig. 1). The highest growth obtained in $\mathrm{T}_{1}$ might be due to low stocking density and lower competition for space. This finding is in conformity with the findings of Asase et al. (2016), who found the highest growth at low stocking density and vice-versa. The results of this study is in similar with the findings of Daudpota et al. (2014) and Kunda et al. (2014), who achieved the best growth at lower stocking densities. This is because less number of similar size fish in net-cage could get more space, food, less competition and dissolved oxygen etc reported by many authors (Irwin et al. 1999, Benetti et al. 2002, Narejo et al. 2005 and 2010 and Hannibal et al. 2011). Diana et al. (2004) reported similar results of the effects of stocking densities and supplemental feeding on growth performance of Nile tilapia.

In this study, the daily growth rate observed in $T_{1}(0.38 \mathrm{~g} /$ day $)$ was significantly higher than that of the other two treatments $(0.28$ and $0.21 \mathrm{~g} /$ day in $\mathrm{T}_{2}$ and $\mathrm{T}_{3}$, respectively; Table 1).This was due to the influence of stocking density in the treatments. In this regard, Smith et al. (1978) reported fish density is an important factor affecting growth and maturation of wild and laboratory fish, besides food supply and its quality, genetics and environmental conditions. The daily growth rates of fish of the treatments in this study are in 
similar to the results obtained by Asase et al. (2016), which ranged from 0.25 to $0.37 \mathrm{~g} \mathrm{day}^{-1}$ in intensive cage culture of tilapia. Growth rates of this study are also in comparable to the daily growth rates reported earlier by Gibtan et al. (2008) and Ridha (2006). Dambo and Rana (1992) reported increasing stocking density of tilapia might have led to falling social supremacy, resulting in lower growth rates. Yi and Lin (2001) have demonstrated that growth rate gradually increases as the stocking density decreases and vice-versa.

Table 1. Growth, SGR, FCR, survival rate and yield (mean \pm SD) of sex-reversed male tilapia fry reared for 60 days in three stocking densities

\begin{tabular}{|c|c|c|c|}
\hline \multirow[t]{2}{*}{ Parameters } & \multicolumn{3}{|c|}{ Stocking density (fry $\mathrm{m}^{-3}$ ) } \\
\hline & 600 & 800 & 1000 \\
\hline Average initial weight (g) & $2.12 \pm 0.11$ & $2.08 \pm 0.06$ & $2.14 \pm 0.19$ \\
\hline Average final weight (g) & $24.10 \pm 0.35^{\mathbf{a}}$ & $18.45 \pm 0.25^{\mathbf{b}}$ & $15.13 \pm 0.28^{\mathrm{c}}$ \\
\hline Daily weight gain (g fish ${ }^{-1}$ day $^{-1}$ ) & $0.38 \pm 0.05^{\mathrm{a}}$ & $0.28 \pm 0.12^{\mathrm{b}}$ & $0.21 \pm 0.12^{\mathrm{c}}$ \\
\hline Specific growth rate $\left(\%\right.$ day $\left.^{-1}\right)$ & $3.29 \pm 0.15^{\mathrm{a}}$ & $3.15 \pm 0.06^{\mathrm{b}}$ & $2.85 \pm 0.19^{c}$ \\
\hline Food conversion ratio (FCR) & $1.46 \pm 0.08^{\mathrm{c}}$ & $1.83 \pm 0.10^{\mathrm{b}}$ & $2.30 \pm 0.16^{\mathrm{a}}$ \\
\hline Survival rate $(\%)$ & $93.0 \pm 5.12$ & $92.0 \pm 5.27$ & $91.0 \pm 5.10$ \\
\hline Gross yield $\left(\mathrm{kg} \mathrm{m}^{-3}\right)$ & $13.44 \pm 1.88$ & $13.57 \pm 1.08$ & $13.77 \pm 1.15$ \\
\hline
\end{tabular}

Values in the same rows with different superscripts $(a, b, c)$ are significantly different $(\mathrm{p}<0.05)$.

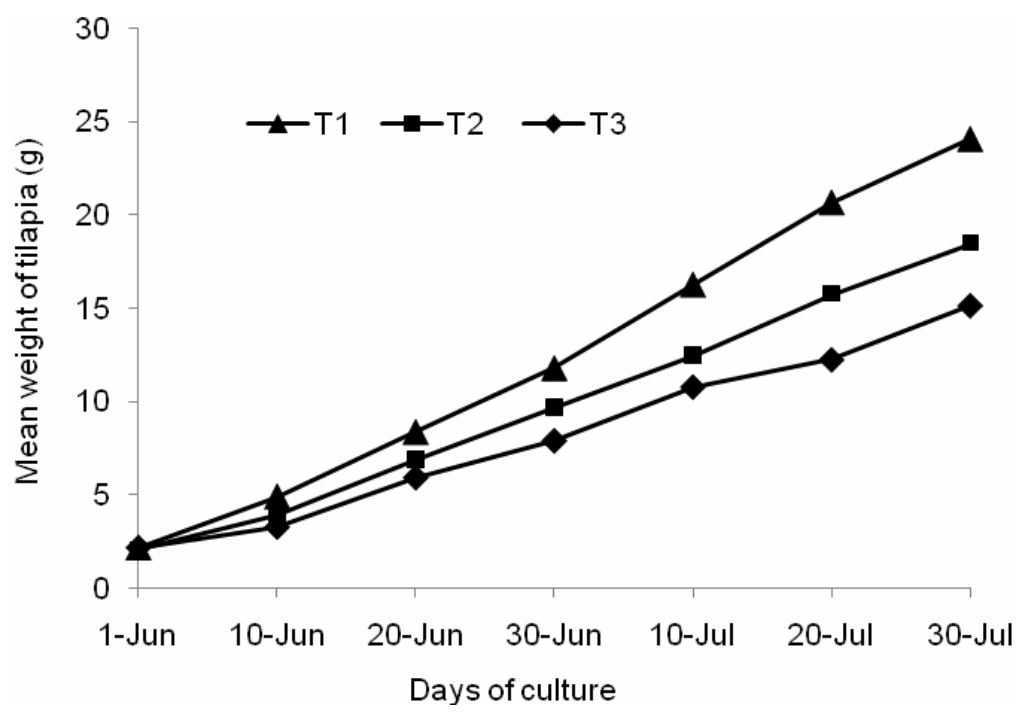

Fig. 1. Growth performance of tilapia under three stocking densities for a period of 60 days. 
Additional evidence on growth differences by the effects of stocking densities were obtained from the results of specific growth rates (Table 1). The highest SGR was obtained in $\mathrm{T}_{1}$ (3.29\%day/fish) and the lowest SGR was in $\mathrm{T}_{3}(2.85 \%$ $\mathrm{day} / \mathrm{fish}$ ) among the treatments. These SGR values are in agreement with the SGR values of $2.71-3.47 \%$ obtained by Kapinga et al. (2014). In the present study, SGR in three treatments were significantly decreased with increasing stocking densities. These results are in consistent with those observed by Asase et al. (2016), Gibtan et al. (2008) and Ridha (2006), who reported SGR decreased with increasing stocking density of tilapia.

FCR, survival rate (\%) and fish yield: Food conversion ratio (FCR) obtained in $\mathrm{T}_{1}$ (1.46) was better than other treatments (Table 1). In this study, FCR increased significantly $(\mathrm{p}<0.05)$ with increasing stocking densities and the best FCR of tilapia was found in $T_{1}$ compared to $T_{2}(1.83)$ and $T_{3}$ (2.30). This result of the present study is in agreement with those obtained by Ouattara et al. (2003), Liti et al. (2005), Bolivar et al. (2006), Ridha (2006), Gibtan et al. (2008) and Asase et al. (2016), who reported FCR increased with increasing stocking densities. Moreover, FCR trend of this experiment is coincided with that obtained by Al-Hafedh (1999), Khattab et al. (2004) and Akbulut et al. (2003). In contrast, some authors (Siddiqui et al. 1989 and Watanabe et al. 1990) reported no remarkable difference was found in FCR of tilapia fed supplementary feed at different stocking densities. The considerable variations in FCR of this study might be due to the variations in fish size and age, stocking density, food quality, hygiene and environmental conditions or other unknown factors.

In this study, the survival rate of tilapia was higher in all treatments (91.093.0\%) but these were not statistically significant (Table 1). Higher survival was found in $\mathrm{T}_{1}(93.0 \%)$ followed by $\mathrm{T}_{2}(92 \%)$ and $\mathrm{T}_{3}(91 \%)$. These results are in consistent with the findings of Daudpota et al. (2014), Ahmed et al. (2014), Kunda et al. (2014), Ridha (2006) and Watanabe et al. (1990). Survival was slightly influenced by stocking densities. It might be due to the high competition for food and space among the fishes. This result of the present study is supported by Yi and Diana (1996) and Yi and Lin (2001). Similarly, Diana et al. (2004) obtained higher survival of tilapia at a low density in ponds. Narejo et al. (2005 and 2010) and Hannibal et al. (2011) reported lower density gave higher survival in cat fishes.

The gross yield of tilapia obtained from all treatments ranged from 13.44 to $13.77 \mathrm{~kg} \mathrm{~m}^{-3}$ with the highest yield $\left(13.77 \mathrm{~kg} \mathrm{~m}^{-3}\right.$ ) in $\mathrm{T}_{3}$ and the lowest (13.44 $\mathrm{kg}$ $\mathrm{m}^{-3}$ ) in $\mathrm{T}_{1}$ (Table 1). It might be associated with the higher number of fry stocked and proper feed intake within the space. However, there was a relation to total production increment with increasing stocking density. These results are in 
agreement with those reported by Ridha (2006), Gibtan et al. (2008), Daudpota et al. (2014) and Kunda et al. (2014) for tilapia cage culture. Similar production scenarios were also obtained in other fish species such as catfish (Islam et al. 2006 and Narejo et al. 2005) and silver perch (Rowland et al. 2004). Asase et al. (2016) and Sugunan and Katiha (2004) reported stocking density and yield have been showed positive relationship in culture-based fisheries in cages and reservoirs, which is in similar with the result of this study.

Table 2. Water quality variables (mean \pm SD) recorded from the cages under different treatments during the study period

\begin{tabular}{lccc}
\hline \multirow{2}{*}{ Variables } & \multicolumn{3}{c}{ Stocking density $\left(\mathrm{fry} \mathrm{m}^{-3}\right)$} \\
\cline { 2 - 4 } & 600 & 800 & 1000 \\
\hline Temperature $\left({ }^{\circ} \mathrm{C}\right)$ & $29.1 \pm 3.8$ & $29.3 \pm 4.9$ & $29.2 \pm 4.7$ \\
Transparency $(\mathrm{cm})$ & $35.23 \pm 2.25$ & $35.92 \pm 3.25$ & $35.87 \pm 2.52$ \\
Dissolved Oxygen concentration $(\mathrm{mg} / \mathrm{l})$ & $4.81 \pm 0.45$ & $4.78 \pm 0.52$ & $4.75 \pm 0.34$ \\
$\mathrm{pH}$ & $7.3(7.0-7.5)$ & $7.3(7.0-7.4)$ & $7.4(7.0-7.4)$ \\
Total alkalinity $(\mathrm{mg} / \mathrm{l})$ & $84.30 \pm 4.42$ & $82.21 \pm 3.70$ & $83.31 \pm 3.60$ \\
$\mathrm{NO}_{3}-\mathrm{N}(\mathrm{mg} / \mathrm{l})$ & $0.13 \pm 0.03$ & $0.11 \pm 0.02$ & $0.13 \pm 0.03$ \\
\hline
\end{tabular}

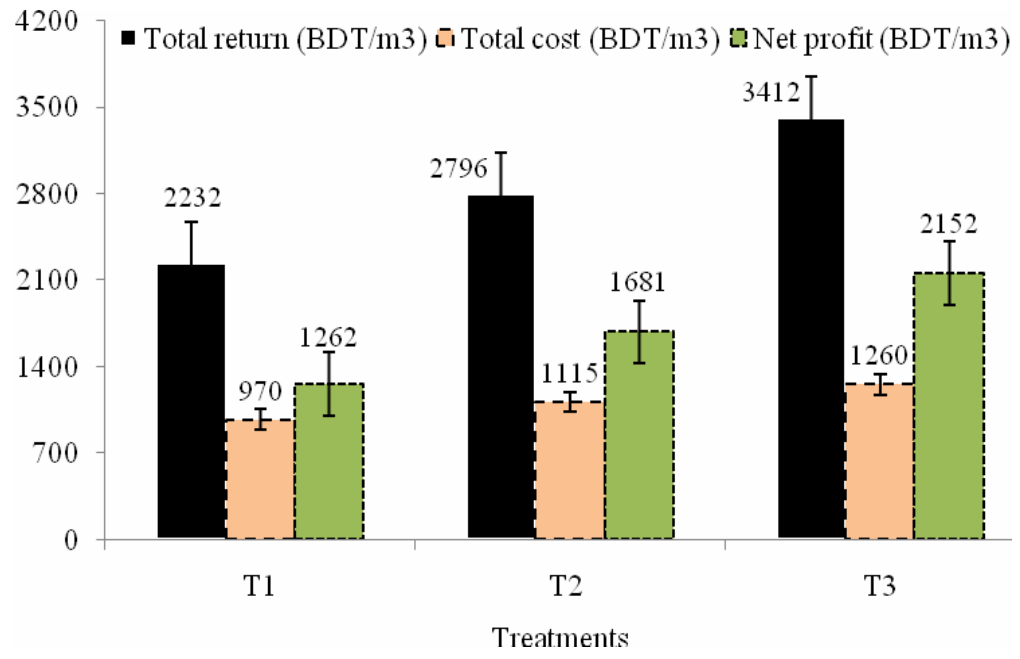

Fig. 2. Economic analysis of tilapia fry production in three treatments based on $\mathrm{m}^{3}$ area.

Net profit: In the present study, although growth rate was found better in low stocking density $\left(\mathrm{T}_{1}\right)$ but it is commercially less feasible because of low profit, which was affected significantly by stocking densities (Fig. 2). The results of this study are in agreement with the results demonstrated by Osofero et al. (2009) and Asase et al. (2016) found significant differences ( $\mathrm{p}<0.05)$ in the profit of tilapia reared in cages at higher stocking densities. Of three treatments, $\mathrm{T}_{3}(1000$ fry $\mathrm{m}^{-3}$ ) was most profitable with a BCR of $2.71: 1$ than that of others. BCR of 
this study is coincided with that reported by Das et al. (2009), who obtained BCR of 2.46-2.65 for fingerling production in cages in Indian reservoirs.

Water quality variables: Water quality variables were similar to each other and were within the suitable ranges of tilapia growth (Table 2).

\section{CONCLUSION}

Optimum utilization of space for maximum production in intensive fish culture practices is well known to accelerate the profitability of fish farms. This study clearly has demonstrated that increasing the stocking density of Nile tilapia fingerlings significantly affects growth, feed conversion ratio and specific growth rate of tilapia reared in haor-based cages. However, stocking density in this study had no significant effect on the survival of fish. The lower individual weight found at harvest at a higher stocking density might be increased using fish feed with higher protein levels (Chang et al. 1988). It reveals from the study that there is no difference in yield at low and higher stocking density, therefore low (600 fry $\mathrm{m}^{-3}$ ) stocking density is desirable. Only in terms of benefit, higher ( 1000 fry $\mathrm{m}^{-3}$ ) stocking density is desirable and economically more profitable.

Acknowledgements: The authors are grateful to Krishi Gobeshona Foundation (KGF), Bangladesh Agricultural Research Council (BARC), Farmgate, Dhaka for funding of this study. Acknowledgements are also due to the reviewer for necessary correction of the manuscript and their valuable suggestions.

\section{LITERATURE CITED}

AHMED, T., HASAN, S. J., HOSSAIN, M. R., A. HAIDAR, I., RUBEL, A. K. M. S. A. and PRAMANIK, M. H. 2014. Assessment on impact of dietary probiotic supplementation on growth indices of mono-sex tilapia (Oreochromis niloticus) cage culture at Dakatiariver, Chandpur, Bangladesh. World Journal of Fish and Marine Sciences 6(5): 441-446.

AKBULUT, B., MAHIN, T., AKSUNGUR, M. and AKSUNGUR, N. 2003. Effect of initial size on growth rate of rainbow trout, Oncorhynchus mykiss reared in cages on the Turkish Black Sea coast. Turkish Journal of Fisheries and Aquatic Sciences 7: 133-136.

AL-HAFEDH,Y. 1999. Effects of dietary protein on growth and body composition of Nile tilapia, Oreochromis niloticus, L. Aquaculture Research 30: 385-393.

ASASE, A., NUNOO, F.K.E. and ATTIPOE, F.Y.K. 2016. Lake-Based Nursery Rearing of Nile Tilapia (Oreochromis niloticus) Fingerlings in Nylon Hapas: Effects of Stocking Density on Growth, Survival and Profitability. Agricultural Sciences 7: 660-669. http://dx.doi.org/10.4236/as.2016. 710062

BenetTI, D. D., MATERA, J. A., STEVEnS, O. M., ALARCON, J. F., FEElEy, M. W., ROTMAN, F. J., MINEMOTO, Y., BANNER-STEVENS, G., FANKE, J., ZIMMERMAN, S. and ELDRIDGE, L. 2002. Growth, survival, and feed conversion rates of hatchery reared mutton snapper, Lutjanus analis cultured in floating net cages. Journal of the World Aquaculture Society 33(3): 349-357.DOI: 10.1111/j.1749-7345.2002.tb00511.x

BEVERIDGE, M. C. M. 1996. Cage Aquaculture. $2^{\text {nd }}$ Edition, Fishing News, Oxford, 346. 
BOLIVAR, R., JIMENEZ, E., SUGUE, R. and BROWN, C. 2006. Effect of stocking sizes on the yield and survival of Nile tilapia (Oreochromis niloticus L.) on-grown in ponds. Asian Fisheries: Diversification and Integration, 6th Asian Fisheries Forum, Kaoshiung, Taiwan. 28pp.

DAMBO, W. B. and RANA, K. J. 1992. Effect of stocking density on growth and survival of Oreochromis niloticus (L.) fry in the hatchery. Aquaculture and Fisheries Management 23: 71-80.

DAS, A. K., VASS, K. K., SHRIVASTAVA, N. P. and KATIHA, P. K. 2009. Cage Culture in Reservoirs in India. (A Handbook) WorldFish Center Technical Manual No. 1948. The World Fish Center, Penang, Malaysia. 24 pp.

DAUDPOTA, A. M., KALHOR, I. B., SHAH, S. A, KALHORO, H. and ABBAS, G.2014.Effect of stocking densities on growth, production and survival rate of red tilapia in hapa at fish hatchery Chilya Thatta, Sindh, Pakistan. Journal of Fisheries 2(3): 180- 186.

DIANA, J. S., YI, Y. and LIN, C. K. 2004. Stocking densities and fertilization regimes for Nile tilapia (Oreochromis niloticus) production in ponds with supplement alfeeding, in Proceedings of the Sixth International Symposium on Tilapia in Aquaculture, R. Bolivar, G. Mair and K. Fitzsimmons, Eds. Manila, Philippines, BFAR, Philippines. 487-499 pp.

GIBTAN, A., GETAHUN, A. and MENGISTOU, S. 2008. Effect of Stocking Density on the Growth Performance and Yield of Nile Tilapia (Oreochromis niloticus L., 1758) in a Cage Culture System in Lake Kuriftu, Ethiopia. Aquaculture Research 39: 1450-1460. http://dx.doi.org/ 10.1111/j.1365-2109.2008.02021.x

HANNiBAL, M. C., AMPARO, L. F. and AURELIO, A. C. 2011. Effect of Stocking Density on Growth Performance, Survival and Production of Silver Pompano, Trachinotus blochii (Lacépède, 1801) in Marine Floating Cages. Asian Fisheries Science 24: 321-330.

IRWIN, S., HALLORAN, J. O. and FITZGERALD, R. D. 1999. Stocking density, growth and growth variation in juvenile turbot, Scophthalmus maximus (Rafineseque). Aquaculture 178: 77-88.

ISLAM M., RAHMAN, M. and TANIKA, M. 2006. Stocking density on production characteristics, costs and risk of producing fingerling channel catfish. North American Journal of Aquaculture 63: 201207.

KAPINGA, I., MLAPONI, E. and KASOZI, N. 2014.Effect of stocking density on the growth performance of sex reversed male Nile tilapia (Oreochromis niloticus) under pond conditions in Tanzania. World Journal of Fish and Marine Sciences 6(2): 156-161.

KHATTAB, Y., ABDEL-TAWWAB, M. and AHMAD, M. 2004. Effect of protein level and stocking density on growth performance, survival rate, feed utilization and body composition of Nile tilapia fry (Oreochromis niloticus L.). In: Proceeding of the Sixth International Symposium on Tilapia in Aquaculture, Manila, Philippines (ed. by R. Bolivar, G. Mair \& K. Fitzsimmons). BFAR, Philippines. 264-276 pp.

KUNDA, M., HARUN-AL-RASHID, A., MORSHED, F., ISLAM, A. and MAZUMDER, S. K. 2014. Production of Tilapia (Oreochromis niloticus) Fingerling in Hapa Using Swim-Up Fry Involving Women in the Haor Region of Bangladesh. IOSR Journal of Agriculture and Veterinary Science 7: 2319-2380. http://dx.doi.org/10.9790/2380-071012935.

LITI, D., FULANDA, B., MUNGUTI, J., STRAIF, M., WAIDBACHER, H. and WINKLER, G. 2005. Effect of open-pond density and caged biomass of Nile Tilapia (Oreochromis niloticus, L.) on growth, feed utilization, economic returns and water quality in fertilized ponds. Aquaculture Research 36: 1535-1543.

MCGINTY, A.S. and RAKOCY, J.E.2006. Tilapia cage culture. SRAC Publication No. 281. Retrieved fromaqua.ucdavis.edu/DatabaseRoot/pdf/281FS.PDF

NASER, M.N. and BARMAN, B.K. 2009. Fish Fingerling Production in Cages by Ultra-poor Households in the Northwest Region of Bangladesh-Technical and Institutional Issues. The WorldFish Center, Bangladesh and South Asia Office Dhaka. 16 p. 
NAREJO, N. T., DAYO, A., DARS, B. A., MAHESAR, H., LAGHARI, M. Y. and LASHARI, P.K. 2010. Effect of Stocking Density on Growth and Survival Rate of Labeorohita (Hamilton) fed with Formulated Feed. Sindh University Research Journal (Sci. Ser.) 42(1): 35-38.

NAREJO, N. T., SALAM, M. A., SABUR, M. A. and RAHMATULLAH, S.M. 2005. Effect of stocking density on growth andsurvival of indigenous catfish, Heteropneustes fossilis (Bloch) reared in cemented cisterns fed on formulated feed. Pakistan Journal of Zoology 37(1): 49-52.

OSOFERO, S. A., OTUBUSIN, S. O. and DARAMOLA, J.A. 2009. Effect of Stocking Density on Tilapia (Oreochromis niloticus, Linnaeus 1757) Growth and Survival in Bamboo-Net Cages Trial. African Journal of Biotechnology 8: 1322-1325.

OUATTARA, N., TEUGELS, G., DOUBA, V. and PHILIPPART, J. 2003. Aquaculture potential of the black-chinned tilapia, Sarotherodon melanotheron (Chiclidae): Comparative study of theeffect of stocking density on growth performance of landlocked and natural populations under cage culture conditionsin Lake Ayame (Cote d'Ivoire). Aquaculture Research 32:1223-1229.

PECHSIRI, J. and YAKUPITIYAGE, A. 2005. A comparative study of growth and feed utilization efficiency of sex-reversed diploid and triploid Nile tilapia, Oreochromis niloticus L. Aquaculture Research36: 45-51.

RIDHA, M.T. 2005. Comparative Study of Growth Performance of Three Strains of Nile Tilapia, Oreochromis niloticus, L. at Two Stocking Densities. Aquaculture Research 37: 172-179. http://dx.doi.org/10.1111/j.1365-2109.2005.01415.x

ROWlAND, S., ALlAN, G., HOLliS, M. and PONTIFEX, T. 2004. Production of Silver perch (Bidyanus bidyanus) fingerlings at three stocking densities in cages and tanks. Aquaculture 229: 193-202.

SHELTON, W.L. 2002. Tilapia culture in the 21st Century. In: Guerrero RD III and Guerrero-del Castillo MR (eds.). Proceedings of the International Forum on Tilapia Farming in the 21st Century (Tilapia Forum 2002), 184 p. Philippine Fisheries Association Inc. Los, Banos, Laguna, Philippines. 1-20 pp.

SIDDIQUI, A., HOWLADER, M. and ADAM, A. 1989. Culture of Nile tilapia, Oreochromis niloticus L., at three stocking densities in outdoor concrete tanks using drainage water. Aquaculture and Fisheries Management 20: 49-57.

SMITH, H., SCHRECK, C. and MAUGHAN, O. 1978. Effect of population density and feeding rate on the fathead minnow (Pimephales promelas). Journal of Fish Biology 12: 449-455.

SUGUNAN, W. and KATIHA, P. 2004. Impact of stocking density on yield in small reservoirs in Andra-Pradesh, India. Fisheries Management and Ecology 11: 193-202.

WATANABE, W. O., CLARK, J. H., DUNHAM, J. B., WICKLUND, R. I. and OLLA, B.L. 1990. Culture of Florida red tilapia in marine cages: the effect of stocking density and dietary protein on growth. Aquaculture 90: 123-1 34.

YI,Y. and LIN, C.K. 2001. Effect of biomass of caged Nile tilapia (Oreochromis niloticus) and aeration on the growth and yields in an integrated cage-cum-pond system. Aquaculture 195: 253-267.

YI, Y., LIN, C. K. and DIANA, J.S. 1996. Influence of Nile tilapia (Oreochromis niloticus) stocking density in cages on their growth and yield in cages and in ponds containing the cages. Aquaculture 146: 205-215. 